\title{
Plasmodium Measurement
}

National Cancer Institute

\section{Source}

National Cancer Institute. Plasmodium Measurement. NCI Thesaurus. Code C100453.

The determination of the amount of Plasmodium present in a sample. 